\title{
Up Grading Capacity Aparatur Desa Melalui Pelatihan di Desa Tegalarum Kabupaten Demak
}

\author{
Moeljono $^{1}$, Nasron Alfiyanto ${ }^{2}$ \\ ${ }^{1,2}$ Fakultas Ekonomi, Universitas Semarang \\ E-mail: ${ }^{1}$ sastro@usm.ac.id, ${ }^{2}$ nasron.alfiyanto@usm.ac.id
}

\begin{abstract}
Abstrak
Kapasitas dan ketrampilan aparat desa dalam melaksanakan tugas administrasi dan tata kelola pelaporan keuangan masih lemah, untuk meningkatkan kapasitas dan ketrampilan para aparatur desa diperlukan adanya pelatihan, untuk meningkatkan kapasitas aparatur pemerintahan desa. Diharapkan melalui kegiatan tersebut akan mendorong tata kelola pemerintahan desa yang akuntabel dan transparan serta melahirkan aparatur desa yang memiliki pengetahuan, sikap dan keterampilan yang baik. Metode kegiatan yang digunakan adalah Participatory Learning and Action. Kegiatan ini dilakukan dengan menekankan pada kegiatan ceramah, diskusi, curah pendapat yang dilakukan secara interaktif dengan aparatur desa dan masyarakat, dilanjutkan dengan kegiatan pelatihan yang relevan dengan materi pemberdayaan masyarakat. Hasil kegiatan pengabdian masyarakat berjalan sesuai dengan rencana yang telah ditetapkan, aparatur desa dan masyarakat memilki respon dan antusias terhadap pelatihan dan tercipta perubahan pengetahuan, sikap dan keterampilan.
\end{abstract}

Kata kunci: Pelatihan Administrasi Pemerintahan Desa, Peningkatan Kapasitas Aparatur

\begin{abstract}
Capacity and skill of village apparatus in carrying out administrative duties and governance of financial reporting is still weak, to increase the capacity and skills of the village apparatus required training, to increase the capacity of apparatus Village governance. It is hoped that these activities will encourage accountable and transparent governance of the village and produce a village apparatus with good knowledge, attitude and skills. The method of activity used is Participatory Learning and Action. This activity is done by emphasizing the activities of lectures, discussions, brainstorming conducted interactively with village and community apparatus, followed by training activities that are relevant to the community empowerment material. The results of the community devotion goes according to the planned plan, village and community apparatus has a response and enthusiastic about the training and created changes in knowledge, attitudes and skills.
\end{abstract}

Keywords: Capacity Building Apparatus, Village Administration Training

\section{PENDAHULUAN}

Desa merupakan satu kesatuan sistem struktur pemerintahan yang secara hirarkis berada paling bawah dan bersentuhan langsung dengan masyarakat. Pengelola pemerintahan desa adalah aparat desa, sehingga para aparat desa inilah yang menjadi ujung tombak pelayanan kepada masyarakat. Maka para aparatur desa dituntut untuk memiliki kemampuan dan ketrampilan yang optimal kepada masyarakat. Namun masih ada aparatur desa yang belum sesuai dengan harapan publik, padahal kompleksitas permasalah yang ada di masyarakat sangat besar, dan aparat harus dituntut untuk memberikan pelayanan yang optimal.

Hal ini telah tersirat dalam UU Nomor 6/2014, bahwa desa merupakan satu kesatuan masyarakat hukum yang memiliki batas wilayah dan berwenang untuk mengatur dan mengurus urusan pemerintahan, kepentingan masyarakat yang diakui dan dihormati dalam sistem pemerintahan Negara Republik Indonesia. Pemerintahan desa sebagai bagian dari sistem sosial 
memiliki peran yang sangat penting dalam pengelolaan modal sosial yang dimiliki oleh masyarakat (Sururi, 2017). Modal sosial, yang ada dimasyarakat adalah nilai-nilai kearifan lokal, sosial dan budaya dan kehidupan gotong royong yang merupakan keterpaduan masyarakat dalam menyikapi permasalahan. Namun, kekuatan modal sosial tersebut harus didukung dengan tata kelola penyelenggaraan administrasi pemerintahan desa dan laporan keuangan desa yang akuntabel dalam rangka pelaksanaan pembangunan yang menyeluruh. Dalam pelaksanaan tata kelola administrasi pemerintahan dan laporan keuangan desa yang akuntabel diperlukan aparatur pemerintahan desa dan masyarakat yang mampu dan memiliki kapasitas dan ketrampilan yang mencukupi.

Hasil analisis situasi sosial ditemukan permasalahan masih rendahnya kemampuan aparatur pemerintahan desa dalam pengelolaan penyusunan kebijakan desa dan manajemen pelayanan desa dan minimnya kemampuan tenaga pengelola keuangan desa sehingga menghambat penyusunan perencanaan keuangan. Dalam hal ini, keberadaaan pendamping desa sebagai tenaga fasilitator masih belum dapat memberikan daya dukung terhadap peningkatan kapasitas aparatur pemerintahan dan masyarakat. Salah satu diantaranya dikarenakan terlalu luasnya jangkauan wilayah kerja pendamping desa yaitu tiga (tiga) pendamping untuk 12 (dua belas) desa dimana idealnya adalah 1 (satu) desa 1 (satu) pendamping desa.

Urgensi tata kelola pemerintahan yang terpenting adalah bagaimana pemerintahan desa mampu meningkatkan kesejahteraan rakyatnya, mampu memberikan pelayanan kepada masyarakat desa, dan mampu meningkatkan daya saing desanya (LAN-RI, 2009). Maka, peningkatan kapasitas aparatur desa dalam tata kelola administrasi pemerintahan desa menjadi hal yang sangat penting. Dalam hal ini, upaya bagi aparatur pemerintahan desa untuk mengikuti pelatihan administrasi pemerintahan desa perlu dilakukan.

Tugas dan tanggung jawab pemerintahan desa adalah menyelenggarakan musrenbang sebagai forum musyawarah perencanaan pembangunan desa dan menyusun RPJMDesa dan RKPDes. Akan tetapi, pada pelaksanaannya musrenbang belum mampu memenuhi keinginan untuk memenuhi kebutuhan dasar masyarakat. Masyarakat belum diberikan ruang untuk menyuarakan aspirasinya karena kepercayaan yang besar terhadap kepala desa dan aparatur desa. Permasalahan merupakan masalah klasik yang ada didesa, meskipun musrembangdes sudah dilaksanakan akan tetapi masih terdapat berbagai permasalahan terkait dengan aspek pengambilan keputusan perencanaan pembangunan desa yang masih bersifat sentralistik dimana masih besarnya pengaruh kepala desa dan aparat desa dalam pengambilan keputusan (Sururi, 2017).

Dengan melihat berbagai permasalahan desa baik dari aspek administrasi pemerintahan maupun tata kelola keuangan terutama dalam meningkatkan ketrampilan dan kapasitas aparatur pemerintahan desa dalam mewujudkan tertib administrasi yang mampu berfungsi sebagai sumber data dan informasi dalam tata kelola penyelenggaraan pemerintahan, maka solusi yang ditawarkan adalah mengadakan kegiatan pengabdian masyarakat melalui pelatihan administrasi pemerintahan desa dan tata kelola keuangan desa yang dilakukan oleh tim pengabdian masyarakat bekerjasama dengan aparatur desa dan masyarakat Desa Tegalarum, Kecamatan Mranggen Kabupaten Demak. Berikut dokumentasi serah terima kerja sama antara tim pengabdian dengan kepala desa Tegalarum, pada gambar 1. 


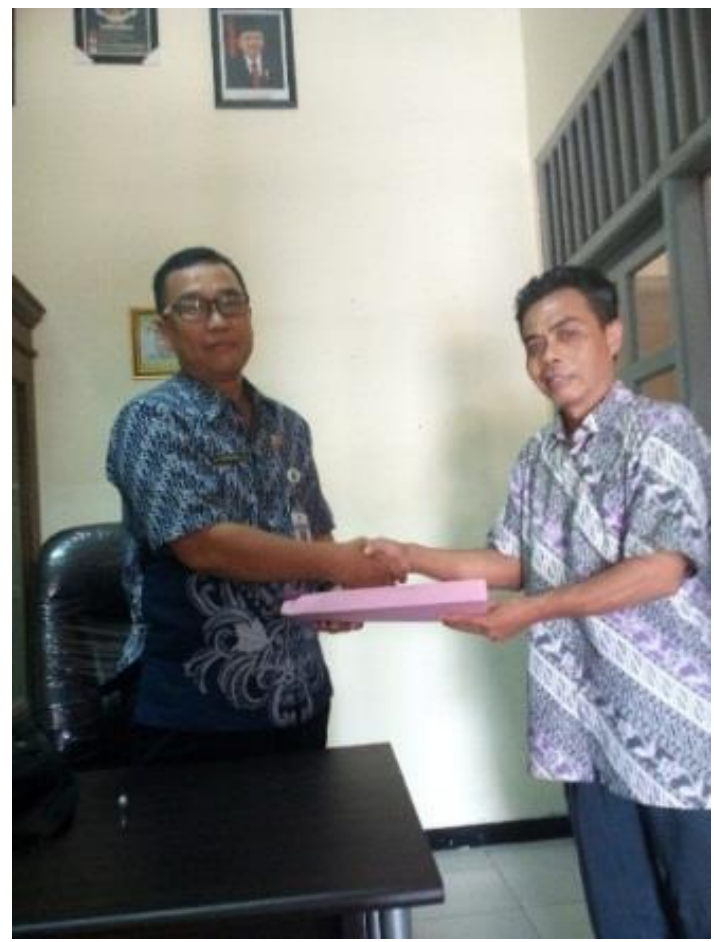

Gambar 1

Naskah Kerja sama antara tim Pengabdian dengan Kepala Desa Tegalarum

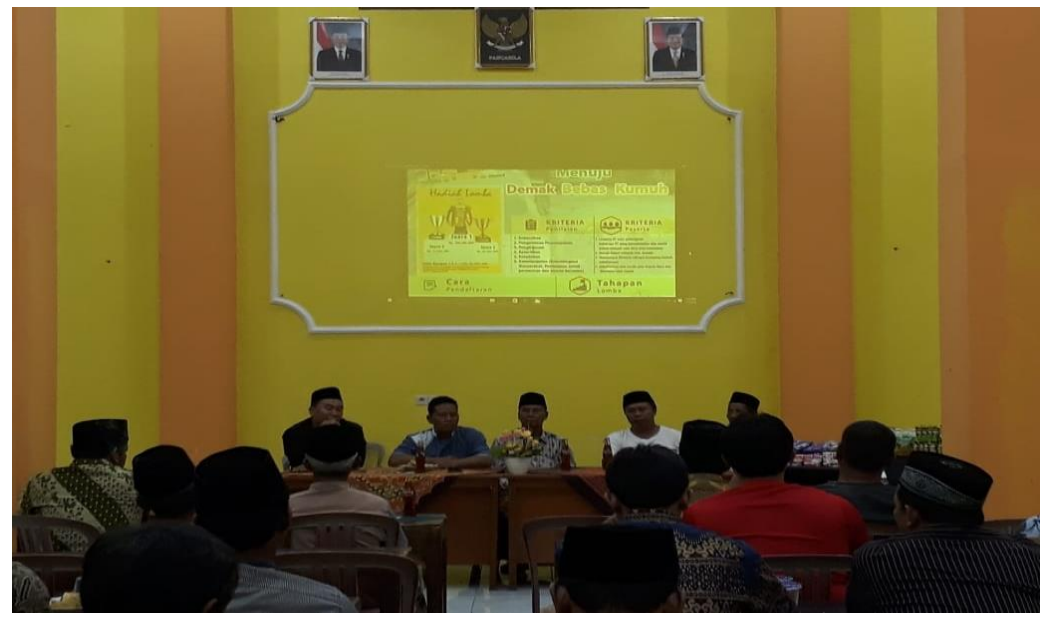

Gambar 2

Tahapan Sosialisasi

Kegiatan pengabdian bertujuan untuk memberdayakan dan meningkatkan keterampilan aparatur dan masyarakat desa tentang administrasi pemerintahan desa, meningkatkan pengetahuan aparatur dan masyarakat desa dengan fokus pada laporan keuangan desa, dan mendorong tertib administrasi pelayanan desa.

\section{METODE PELAKSANAAN}

Metode yang digunakan adalah Participatory Learning and Action (PLA) merupakan bentuk baru dari metode pemberdayaan masyarakat yang sebelumnya lebih dikenal dengan "Learning by Doing" atau belajar sambil bekerja (Phuyal, 2008; IIED, 2013 dalam Mardikanto, 2013), Participatory Learning Action merupakan proses belajar secara berkelompok yang dilakukan secara interaktif dalam suatu proses kerja (Appel dkk, 2012). Konsep kegiatan PLA 
dilakukan dengan menekankan pada kegiatan ceramah, diskusi, curah pendapat yang dilakukan secara interaktif dengan anggota kelompok dan dilanjutkan dengan aksi atau kegiatan riil yang relevan dengan materi pemberdayaan masyarakat (Theresia, 2014).

Kegiatan ini diikuti oleh aparatur pemerintahan Desa Tegalarum, berjumlah 7 (tujuh) orang dan perwakilan dari masyarakat berjumlah 10 (sepuluh) orang. Pelaksanaan kegiatan melalui tiga tahap yaitu tahap awal, tahap inti dan tahap akhir. Secara umum tahapan kegiatan pengabdian ini dapat dilihat pada gambar 2 .

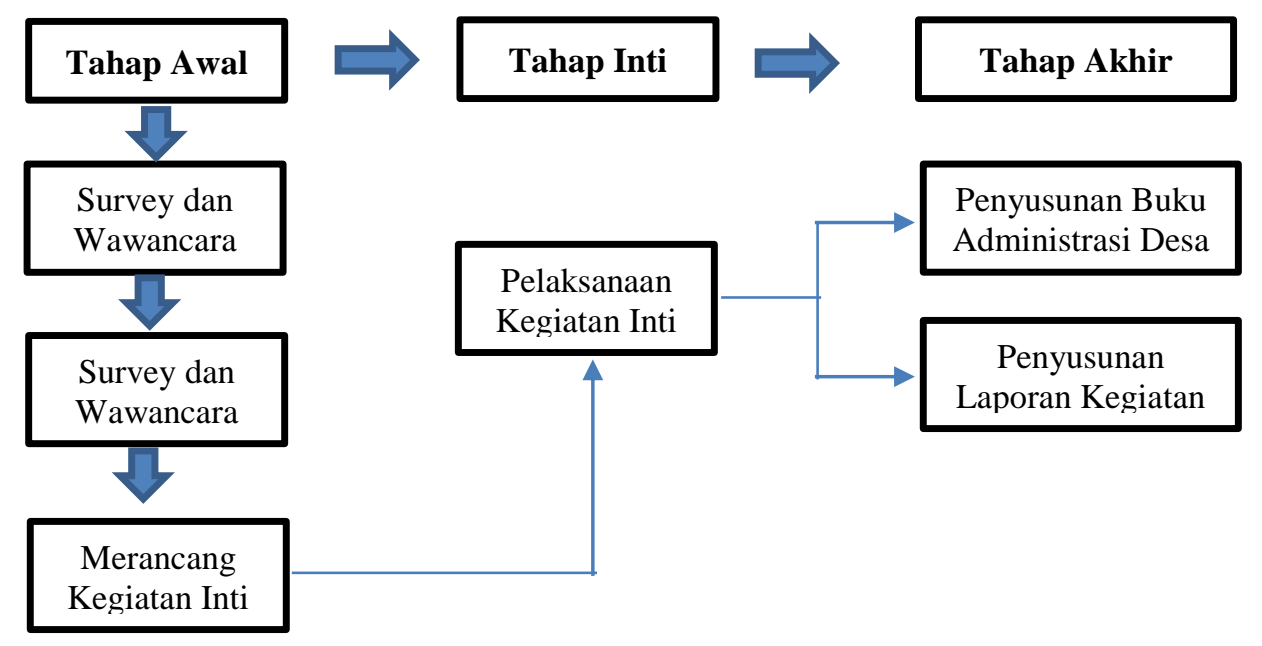

Gambar 2.

Bagan Tahapan Kegiatan

Berikut penjelasannya pada tahap kegiatan.

1. Tahap awal.

Kegiatan pada tahap ini meliputi

a. Survey.

Merupakan kegiatan awal untuk menganilis dan mencari informasi secara menyeluruh mengenai permasalahan agar dapat ditemukan solusi yang tepat sasaran.

b. Kelengkapan administrasi dilakukan sebagai prosedur formal untuk melegalkan kegiatan pengabdian

c. Merancang dan menyusun kegiatan pelatihan yang sesuai dengan tujuan pelaksanaan.

2. Tahap inti.

Proses kegiatan pada tahap ini adalah fokus pada kegiatan pengabdian yang dilakukan yaitu pendampingan dan bimbingan melalui serangkaian pelatihan. Agenda kegiatan pelatihan yang dilakukan adalah tata kelola administrasi pemerintahan desa dan manajemen pemerintahan desa.

Target sasaran peserta pelatihan adalah aparatur pemerintahan desa dan masyarakat. Selanjutnya dilakukan kegiatan evaluasi dengan melihat indikator tahapan perubahan perilaku berdasarkan skala 0-25 kategori rendah, skala 26-50 kategori kurang, skala 51-75 kategori cukup dan skala 76-100 kategori tinggi.

3. Tahap akhir.

Ada tiga kegiatan dalam tahap ini yaitu:

a. Evaluasi kegiatan yang akan dilakukan perkegiatan dan secara menyeluruh;

b. Penyusunan modul pelayanan desa.

c. Penyusunan Laporan Pengabdian 


\section{HASIL DAN PEMBAHASAN}

Kegiatan pendampingan ini dilakukan selama 1 (satu) bulan yaitu 1 sampai dengan 31 Maret 2019. Tahap Awal (Survey dan Analisis Situasi Sosial) Pada tahap ini kegiatan survey dan analisis situasi dilakukan dengan melibatkan beberapa warga desa dengan tujuan untuk melakukan identifikasi potensi dan permasalahan yaitu aspek kelembagaan desa, aspek manajemen pelayanan aparatur desa, aspek transparansi penggunaan dan pelaporan keuangan desa, aspek pembangunan desa, aspek kesehatan, aspek infrastruktur (fasilitas umum dan fasilitas sosial desa) dan aspek kebijakan pemerintahan desa.

Kegiatan difokuskan terhadap sejumlah wilayah dan melakukan wawancara terhadap jumlah kepala keluarga. Hasil survey selanjutnya diolah dengan membuat matrik hasil survey dan wawancara. Hasil pengamatan dapat dilihat pada Tabel 1

Tabel 1.

Hasil Survey dan Analisis Situasi Sosial

\begin{tabular}{cll}
\hline No & \multicolumn{1}{c}{ Aspek } & \multicolumn{1}{c}{ Hasil Survey dan Wawancara } \\
\hline 1 & Kelembagaan Desa & $\begin{array}{l}\text { Desain kelembagaan menggunakan pola tradisional } \\
\text { Kurang maksimal dalam memberikan pelayanan kepada } \\
\text { masyarakat dari sisi kemudahan dan kecepatan. }\end{array}$ \\
3 & Manajemen pelayanan Desa & Tata Kelola Keuangan Desa \\
& & $\begin{array}{l}\text { Proses musyawarah desa, sosialisasi penggunaan dan } \\
\text { pelaporan keuangan desa sudah dilakukan, masyarakat } \\
\text { dapat mengakses dengan mudah namun, belum } \\
\text { memenuhi kepentingan publik. }\end{array}$ \\
4 & Pembangunan Desa & $\begin{array}{l}\text { Pelaksanaan musrenbang sudah dilaksanakan, namun } \\
\text { belum menyentuh aspek dasar kebutuhan masyarakat }\end{array}$ \\
5 & Kesehatan & $\begin{array}{l}\text { Perilaku hidup masyarakat untuk hidup sehat sangat } \\
\text { tinggi meskipun terdapat keterbatasan }\end{array}$ \\
6 & Infrastruktur & $\begin{array}{l}\text { Pembangunan infrastruktur sudah dilakukan, meskipun } \\
\text { belum menyentuh aspek kebutuhan dasar masyarakat } \\
\text { Pengambilan keputusan bersifat sentralistik dan kebijakan } \\
\text { dilakukan secara top down }\end{array}$ \\
7 & Kebijakan &
\end{tabular}

\section{Tahap Inti (Kegiatan Pendampingan)}

Pada tahap ini, kegiatan yang dilakukan adalah:

a) Sosialisasi program;

Sosialisasi pada masyarakat diberikan terkait dengan program yang akan dilaksanakan. Kegiatan dilaksanakan di Kantor desa dengan dihadiri oleh masyarakat. Pada tahap ini, tim pengabdian masyarakat melakukan sosialisasi program pelatihan administrasi pemerintahan desa dan pelatihan tata kelola laporan keuangan desa yang bertempat di Pendopo Desa Tegalarum. Berikut dokumentasi sosialisasi pelaksanaan kegiatan, tertera pada gambar 3 . 


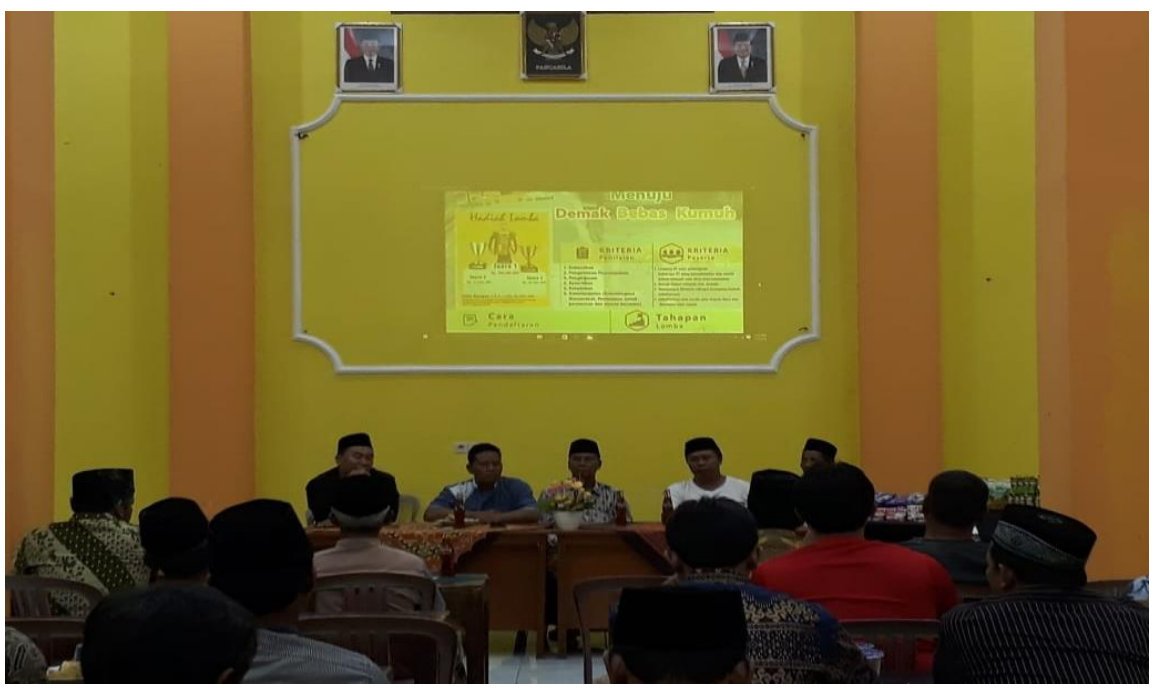

Gambar 2

Tahapan Sosialisasi

Kegiatan sosialisasi program yang diadakan pada tanggal 2 Maret 2019 ini dihadiri oleh kepala desa, ketua BPD dan masyarakat bertempat di Pendopo Desa Tegalarum. Berikut dapat dilihat tampilan Pendopo Desa Tegalarum Kecamatan Mranggen, pada Gambar 4.

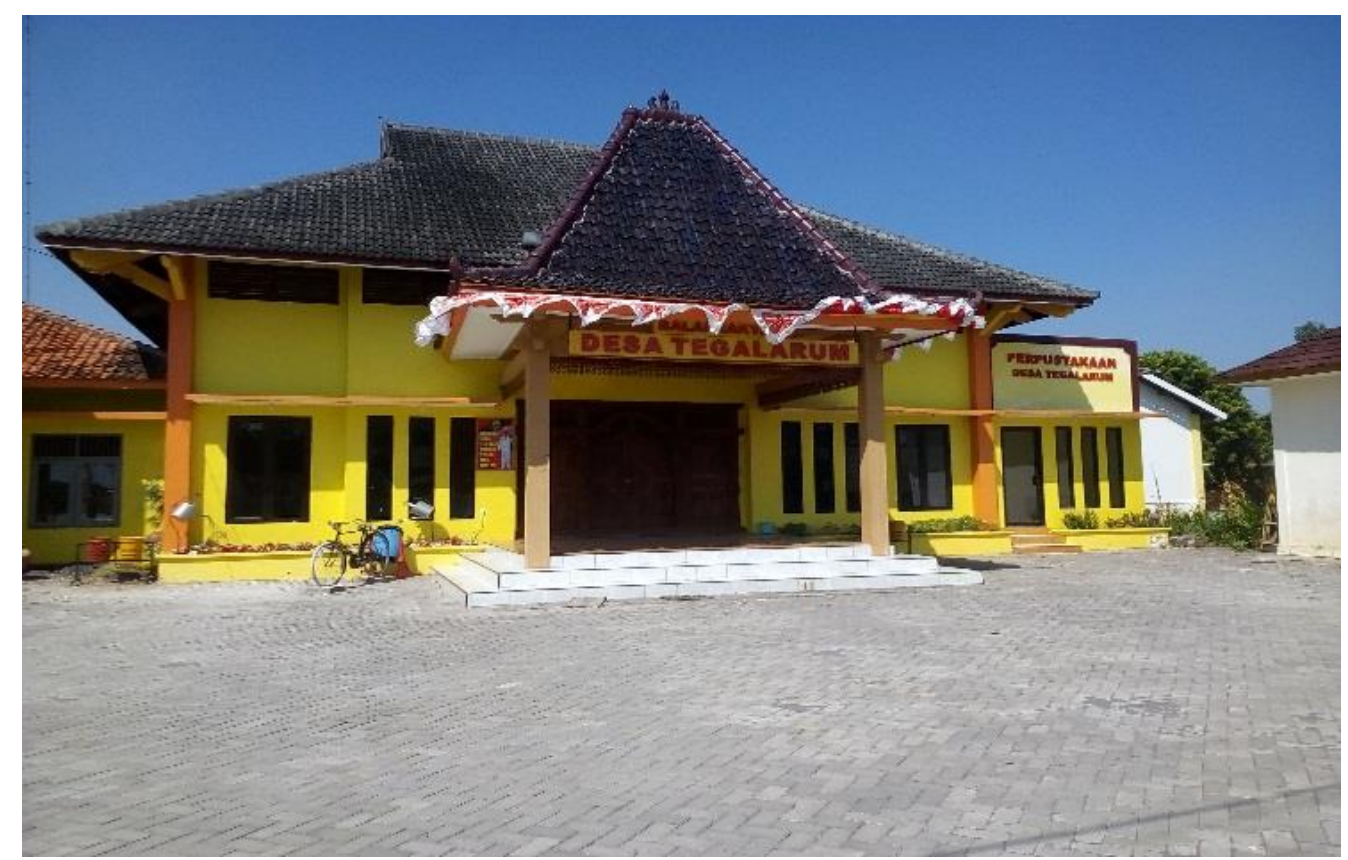

Gambar 4

Pendopo Desa Tegalarum, Kecamatan Mranggen

Pada saat pelatihan respon yang diberikan masyarakat sangat antusias dan mendorong agar kegiatan pelatihan dapat dilaksanakan secara berkelanjutan. Harapan kepala desa dalam sambutannya agar kegiatan pengabdian ini dapat meningkatkan pemahaman dan keterampilan aparatur pemerintahan desa serta menjadi motivasi dalam memberikan pelayanan optimal kepada masyarakat. Jadual Pelaksanaan kegiatan pelatihan administrasi pemerintahan desa dan tata kelola laporan keuangan desa tertera pada Tabel 2. 
Tabel 2.

Jadual Pelatihan Administrasi Pemerintahan Desa dan Tata Kelola Laporan Keuangan Desa

\begin{tabular}{clccl}
\hline No & \multicolumn{1}{c}{ Kegiatan } & Waktu & \multicolumn{1}{c}{ Ket. } \\
\hline 1 & Sosialisasi program & 2 Maret 2019 & Tim \\
2 & $\begin{array}{l}\text { Kegiatan } \\
\text { Administrasi Pelatihan }\end{array}$ & 9 Maret 2019 & $\begin{array}{l}\text { Nasron Alfiyanto. SE. } \\
\text { M.Si. }\end{array}$ \\
& $\begin{array}{l}\text { Desa } \\
3\end{array}$ & $\begin{array}{l}\text { Kegiatan Pelatihan Tata Kelola } \\
\text { Keuangan Desa }\end{array}$ & 16 Maret 2019 & Moeljono. MM, M.Si \\
4 & $\begin{array}{l}\text { Penyusunan Laporan Kegiatan } \\
\text { 30 Maret 2019 }\end{array}$ & Tim \\
\hline
\end{tabular}

\section{b) Kegiatan Pendampingan Pelatihan Administrasi Pemerintahan Desa}

Kegiatan ini diikuti oleh aparatur pemerintahan desa dan masyarakat. Materi-materi yang diberikan dalam kegiatan pendampingan ini adalah dokumen desa seperti buku peraturan desa, kumpulan keputusan kepala desa, buku inventaris desa, buku aparatur pemerintahan desa, buku agenda, buku lembaran desa dan berita desa.

Kegiatan yang dilaksanakan pada tanggal 9 Maret 2019 ini diikuti oleh seluruh aparatur pemerintahan desa yang berjumlah 9 (sembilan) orang dan 10 (sepuluh) orang dari perwakilan masyarakat. Kegiatan yang dilaksanakan adalah memberikan pengenalan teori dan praktek penyusunan buku administrasi pemerintahan desa.

Untuk mengetahui tingkat keberhasilan pencapaian kegiatan ini dilakukan evaluasi melalui indikator tahapan perubahan perilaku pengetahuan, sikap dan keterampilan yang dapat dilihat pada tabel 3.

Tabel 3

Indikator Tahapan Perubahan Perilaku dan Pemahaman Materi Administrasi Pemerintahan Desa

\begin{tabular}{llc}
\hline \multicolumn{1}{c}{ Tujuan } & \multicolumn{1}{c}{ Indikator } & $\begin{array}{c}\text { Pemahaman } \\
(\mathbf{\%})\end{array}$ \\
\hline Pengetahuan & $\begin{array}{l}\text { 1. Peserta pelatihan mengetahui dan memahami } \\
\text { penyusunan buku peraturan desa }\end{array}$ & $85 \%$ \\
& $\begin{array}{l}\text { 2. Peserta pelatihan mampu memahami buku } \\
\text { keputusan kepala desa dan buku agenda }\end{array}$ & $85 \%$ \\
& $\begin{array}{l}\text { 3. Peserta pelatihan mengerti jenis-jenis buku } \\
\text { inventaris desa }\end{array}$ & $80 \%$ \\
4. Peserta pelatihan mampu memahami buku \\
lembaran dan berita desa \\
Sikap & $\begin{array}{l}\text { Peserta pelatihan memperhatikan dan menanggapi } \\
\text { pentingnya administrasi pemerintahan desa }\end{array}$ & $80 \%$ \\
Keterampilan & $\begin{array}{l}\text { Peserta pelatihan mampu dalam menyusun buku } \\
\text { administrasi pemerintahan desa }\end{array}$ & $75 \%$ \\
\hline Rata-rata & & $\mathbf{8 0 \%}$ \\
\hline
\end{tabular}

Pada tabel 3 digambarkan bahwa rata-rata perubahan peserta pelatihan sebesar $80 \%$ atau berada pada kategori tinggi, hal ini disebabkan kesadaran dan kemauan masyarakat untuk mengikuti kegiatan pelatihan sangat besar, dengan demikian dapat diindikasikan bahwa tingkat perubahan perilaku peserta pelatihan setelah mengikuti kegiatan pelatihan cukup baik, sedangkan sisanya sebesar 20\% perlu dilakukan evaluasi lebih lanjut. Dan adapun dokumentasi pada saat dilakukannya agenda pelatihan administrasi pemerintahan desa, seperti tertera pada gambar 4. 


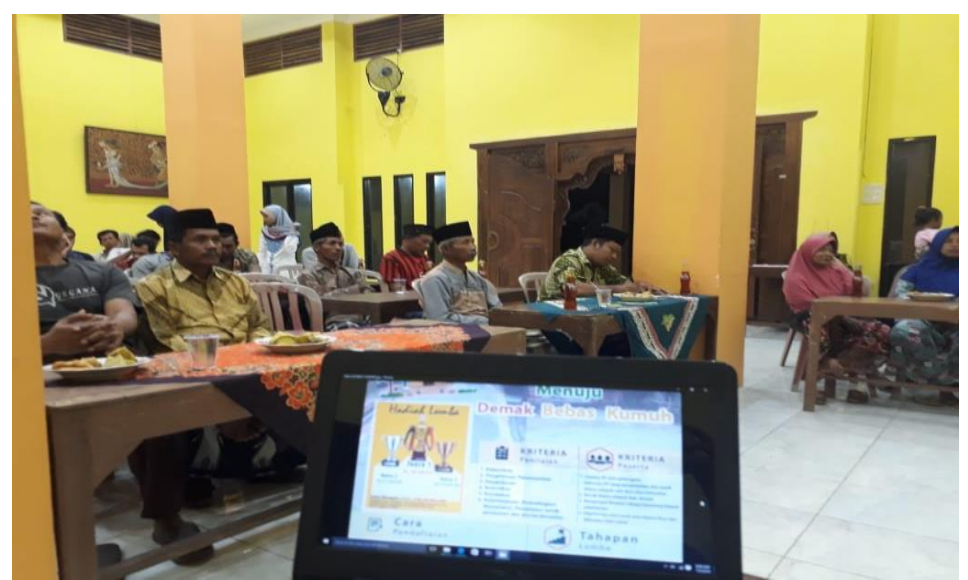

Gambar 2

Pelatihan Administrasi Pemerintahan Desa

\section{c) Pendampingan pelatihan Tata Kelola Keuangan Desa.}

Pada kegiatan ini, difokuskan untuk dapat mempraktekkan dan menyusun laporan pertanggungjawaban APBDes. Output yang diharapkan adalah peserta pelatihan terutama aparatur desa mampu menyusun dan menyampaikan laporan atas pelaksanaan tugas, kewenangan, hak, dan kewajibannya dalam pengelolaan keuangan desa. Laporan tersebut bersifat periodik yaitu semesteran dan tahunan, yang disampaikan ke bupati dan ke BPD. Laporan dimaksud terdiri dari:

1. laporan realisasi pelaksanaan APBDesa;

2. laporan pertanggungjawaban realisasi pelaksanaan APBDesa kepada bupati setiap akhir tahun anggaran;

3. laporan realisasi penggunaan dana desa.

Kegiatan dilaksanakan pada tanggal 16 Maret 2019 dan diikuti oleh 7 (tujuh) orang aparatur pemerintahan desa dan 10 (sepuluh) perwakilan masyarakat.

Sementara itu, untuk mengetahui bagaimana tingkat keberhasilan pencapaian kegiatan pendampingan pelatihan laporan keuangan desa dilakukan evaluasi melalui indikator tahapan perubahan perilaku pengetahuan, sikap dan keterampilan yang dapat dilihat pada tabel 4 .

Tabel 4.

Indikator Tahapan Perubahan Perilaku dan Pemahaman Materi Laporan Keuangan Desa

\begin{tabular}{clc}
\hline \multicolumn{1}{c}{ Tujuan } & \multicolumn{1}{c}{ Indikator } & Pemahaman (\%) \\
\hline Pengetahuan & $\begin{array}{l}\text { Peserta Pelatihan memahami penyusunan laporan } \\
\text { realisasi pelaksanaan APBDesa }\end{array}$ & $75 \%$ \\
& $\begin{array}{l}\text { Peserta Pelatihan mamp menyusun laporan } \\
\text { pertanggungjawaban Realisasi pelaksanaan }\end{array}$ & $75 \%$ \\
APBdesa setiap akhir tahun anggaran, & $75 \%$ \\
Sikap & $\begin{array}{l}\text { Peserta Pelatihan memperhatikan dan menanggapi } \\
\text { pentingnya laporan keuangan desa }\end{array}$ & $75 \%$ \\
Keterampilan & $\begin{array}{l}\text { Peserta Pelatihan mengetahui dan memahami } \\
\text { penyusunan laporan realisasi \& } \\
\text { pertanggungjawaban keuangan desa }\end{array}$ & \\
\hline Rata-rata & & $75 \%$ \\
\hline
\end{tabular}

Pada tabel 4 digambarkan bahwa rata-rata perubahan perilaku aparatur dan masyarakat desa sebesar 75\% atau berada pada kategori cukup. Hal ini disebabkan aparatur pemerintahan desa dan masyarakat menilai bahwa penyusunan laporan keuangan desa sangat penting untuk dipahami dan diketahui oleh seluruh masyarakat. 
Hasil tersebut sebagai indikasikator tingkat perubahan perilaku aparatur pemerintahan desa dan masyarakat setelah mengikuti kegiatan pelatihan cukup baik, sedangkan sisanya sebesar $25 \%$, agar dilakukan evaluasi lebih lanjut. Berikut dokumentasi kegiatan pelatihan tata kelola pelaporan keuangan desa di Desa Tegalarum Kecamatan Mranggen Kabupaten Demak, seperti tertera pada gambar 5 .

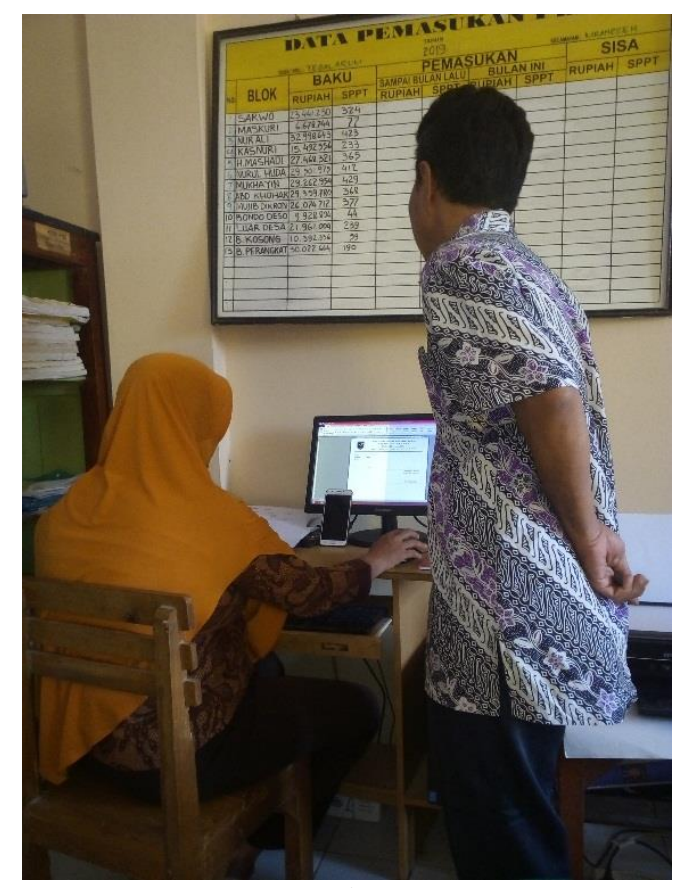

Gambar 3

Kegiatan Pelatihan Tata Kelola Pelaporan Keuangan Desa

\section{Tahap Akhir Kegiatan}

Pada tahap ini ada 2 (dua) kegiatan dalam yaitu pendampingan penyusunan buku administrasi pemerintahan desa dan laporan keuangan desa. Pada tahap ini, peserta pelatihan menyusun dan mempraktekannya bersama-sama tim pengabdian.

Kegiatan yang dilaksanakan selama 1 (satu) hari tersebut yaitu pada tanggal 30 Maret 2019 sekaligus sebagai tahap evaluasi untuk memantau dan menilai sejauhmana masyarakat dapat mempraktekkan hasil pelatihan yang telah diberikan.

\section{KESIMPULAN DAN SARAN}

Kesimpulan harus mengindikasi secara jelas hasil-hasil yang diperoleh, kelebihan dan kekurangannya, serta kemungkinan pengembangan selanjutnya. Kesimpulan dapat berupa paragraf, namun dapat juga berbentuk poin-poin dengan menggunakan numbering atau bullet. Saran-saran untuk untuk penelitian lebih lanjut untuk menutup kekurangan penelitian.

Dari kegiatan yang telah dilaksanakan, dapat disimpulkan beberapa hal yaitu tingkat keberhasilan pencapaian dengan menggunakan indicator perubahan perilaku untuk kegiatan pelatihan administrasi pemerintahan desa dan laporan keuangan adalah sebesar $80 \%$ dan $75 \%$ yaitu berada pada kategori cukup. Aparatur Pemerintahan dan masyarakat Desa Tegalarum Kecamatan Mranggen Kabupaten Demak sebagai mitra pengabdian masyarakat memiliki respon dan antusias yang sangat besar terutama dalam proses pelatihan walaupun dengan segala keterbatasan yang dimiliki. Proses kegiatan pengabdian masyarakat masyarakat di Desa Tegalarum Kecamatan Mranggen Kabupaten Demak, melalui kegiatan pelatihan administrasi pemerintahan desa dan laporan keuangan berjalan sesuai dengan rencana dan target yang telah ditetapkan. 
Adapun saran dalam kegiatan ini adalah penyusunan laporan dilakukan secara mandiri dan dapat mensosialisasikan hasil pelatihan kepada seluruh masyarakat dan kegiatan pelatihan administrasi Pemerintahan Desa dan pelaporan keuangan desa dilaksanakan secara berkelanjutan.

\section{DAFTAR PUSTAKA}

[1] Lembaga Administrasi Negara. 2009. Peningkatan Kapasitas Aparatur Desa. Pusat Kajian Kinerja Otonomi Daerah: Jakarta.

[2] Mardikanto T, Soebiato P, 2013. Pemberdayaan Masyarakat dalam Perspektif Kebijakan Publik. Alfabeta: Bandung.

[3] Sururi, A., \& Mulyasih, R. (2017). Pemberdayaan Masyarakat melalui Inovasi Perencanaan Pembangunan berbasis 4R (Rembug, Rencana, Realisasi dan Rawat) di Desa Cilangkap Kecamatan Wanasalam sebagai Pilar Utama Kebijakan Partisipatif dan Gotong Royong. ENGAGEMENT, 1(2), 218-238.

[4] Sururi, A., \& Mulyasih, R. (2017). Penguatan Kapasitas Masyarakat Melalui Inovasi Formulasi Kebijakan Perencanaan Pembangunan Partisipasif di Kecamatan Wanasalam Kabupaten Lebak. Wikrama Parahita: Jurnal Pengabdian Masyarakat, 1(1), 5-18.

[5] Theresia, Aprillia, atll, 2014. Pembangunan Berbasis Masyarakat. Bandung: Alfabeta

[6] Undang-undang Nomor 6 Tahun 2014 Tentang Desa 